\title{
Health Literacy: The Reality of a Community in Alto Minho
}

\author{
Odete Maria Azevedo Alves ${ }^{a-c}$ Maria Carminda Soares Morais ${ }^{b}, d$ \\ Catarina Carvalhido Barreiras ${ }^{b, c}$ Marisa de Jesus Gomes Cruz ${ }^{\text {b, c }}$ \\ Ana Maria Damião Lopes Limab, c \\ a Instituto de Ciências Biomédicas de Abel Salazar, Universidade do Porto, Porto, Portugal; \\ ${ }^{\text {b} E s c o l a ~ S u p e r i o r ~ d e ~ S a u ́ d e ~ d e ~ V i a n a ~ d o ~ C a s t e l o, ~ I n s t i t u t o ~ P o l i t e ́ c n i c o ~ d e ~ V i a n a ~ d o ~ C a s t e l o, ~ V i a n a ~ d o ~ C a s t e l o, ~ P o r t u g a l ; ~}$ \\ ' Unidade Local de Saúde do Alto Minho, EPE, Viana do Castelo, Portugal; ' Centro de Estudos e Investigação em \\ Saúde da Universidade de Coimbra, Coimbra, Portugal
}

\section{Keywords}

Health promotion $\cdot$ Health literacy $\cdot$ Knowledge and empowerment

\section{Abstract \\ Background: Limited health literacy makes decision-making difficult and has implications for individual health, costs, and the organization of health systems in general, and therefore must be studied in different communities, allowing an ade- quate response to the specificities, particularities, and po- tentialities of each local situation. Methods: To evaluate the level of health literacy and relate it to sociodemographic variables (sex, age group, education, and employment situ- ation), this study was carried out in a population of 3,927 individuals from a parish of Alto Minho with a random prob- abilistic sample of 351 individuals, stratified by age and sex, with a sampling error of $5 \%$. This is a quantitative, observa- tional, and cross-sectional study. Results: The majority of re- spondents were female $(54.1 \%)$, with a mean age $( \pm S D)$ of $44.94 \pm 19.048$ years, had higher education qualifications (74.0\%), and were professionally active (61.0\%). The health}

\section{KARGER}

E-Mail karger@karger.com www.karger.com/pjp

Karger Open access (c) 2019 The Author(s). Published by S. Karger AG, Basel on behalf of NOVA National School of Public Health

This article is licensed under the Creative Commons AttributionNonCommercial-NoDerivatives 4.0 International License (CC BYNC-ND) (http://www.karger.com/Services/OpenAccessLicense) Usage and distribution for commercial purposes as well as any distribution of modified material requires written permission. literacy of this community is limited (66.1\%) in its different domains. In all of them, individuals assume easy and very easy activities that do not involve critical analysis and interpretation, and reveal greater difficulty in those that require this ability. Statistically significant relationships were found between the level of health literacy and schooling $\left(x^{2}=\right.$ 33.552 and $p \leq 0.001)$. Conclusion: This study allowed us to recognize that the health literacy level of this Alto Minho community is limited. Also, the fact that it is related to certain sociodemographic variables sheds light on the health literacy level of the people of this community and on the challenges of promoting it.

(c) 2019 The Author(s). Published by S. Karger AG, Basel on behalf of NOVA National School of Public Health

\section{Literacia em saúde: a realidade de uma comunidade do Alto Minho \\ Palavras-Chave \\ Promoção da Saúde · Literacia em Saúde · Alfabetização em Saúde e Capacitação}

Odete Maria Azevedo Alves Moradia das Lages, 7 Pereiras, Vila Nova de Muía PT-4980-827 Ponte da Barca (Portugal) E-Mail odetemaalves@hotmail.com 


\section{Resumo}

Introdução: A Literacia em Saúde limitada condiciona os indivíduos nas suas decisões e acarreta implicações na saúde individual, nos custos e na organização dos sistemas de saúde em geral, pelo que urge o seu estudo em diferentes comunidades permitindo uma resposta adequada às especificidades, particularidades e potencialidades de cada realidade. Métodos: Com o objetivo de avaliar o nível de Literacia em Saúde e relacioná-lo com as variáveis sociodemográficas (sexo, grupo etário, escolaridade e situação face ao emprego), realizou-se este estudo numa população de 3,927 indivíduos de uma freguesia do Alto Minho com amostra probabilística aleatória, de 351 indivíduos, estratificada por idade e sexo, com um erro amostral de 5\%. Trata-se de um estudo quantitativo, observacional analítico e transversal. Resultados: A maioria dos inquiridos é do sexo feminino (54.1\%), com idade média \pm desvio padrão de $44.94 \pm 19.048$ anos, possui habilitações literárias superiores à escolaridade obrigatória (74.0\%) e encontra-se em situação profissionalmente ativa (61.0\%). A Literacia em Saúde desta comunidade é limitada (66.1\%) nos seus diferentes domínios. Em todos eles os indivíduos assumem como fácil e muito fácil atividades que não envolvem análise crítica e interpretação e revelam maior dificuldade nas que exigem essa capacidade. Foi encontrada relação estatisticamente significativa do nível de Literacia em Saúde com a escolaridade $\left(x^{2}=33.552\right.$ e $p \leq 0.001)$. Conclusão: Este estudo permitiu conhecer o nível de LS desta comunidade do Alto Minho que se caracteriza como limitado. Também o facto de estar ou não relacionada com determinadas variáveis sociodemográficas permitiu a reflexão sobre a LS das pessoas desta comunidade e sobre os desafios da promoção da mesma.

(c) 2019 Sociedade Portuguesa de Gastrenterologia Publicado por S. Karger AG, Basel

\section{Introduction}

People's empowerment in relation to their own health is now one of the central goals in health at the European level [1], and in Portugal this is framed through strategies delimited in the National Health Plan [2] and in the Literacy Program in Health and Care Integration [3], materialized through the SNS + Proximity Project [4], among others. In these two programs the purpose is to promote the literacy and empowerment of citizens, making them more autonomous and responsible in relation to their own health and that of those who depend on them.
Studies of health literacy (HL) have been carried out in different countries, including in Portugal [5-7]. Nevertheless, it is important to study this in different smaller communities so that in-depth knowledge can enable health professionals to carry out interventions that are more adjusted to their local specificities. HL is understood as the "set of cognitive and social skills and the ability of individuals to understand and use information in order to promote and maintain good health" [8].

According to Nutbeam [9] HL can be functional, interactive, or critical. The level of functional HL is characterized by the presence of basic reading and writing abilities. The interactive aspect involves social capacities that allow the active participation and autonomous and preventive use of health care (HC). Finally, the critical HL level relates to the capacity for critical analysis of relevant information.

According to several studies $[5,10]$, a limited level of HL conditions individuals to make appropriate decisions. This limitation leads to a lower capacity for managing chronic diseases and low adherence to therapy, which will be reflected in an increase in hospitalization and rehospitalization rates, an increased morbidity rate, and premature death [9], with implications for the costs and organization of health and social systems [11].

Evidence of the cost-effectiveness of interventions to improve HL levels lacks research. A systematic review in 2009 showed that additional costs associated with limited HL levels can be substantial (3-5\% of the total cost of HC) [11], but on the other hand it emphasized that some studies are inconclusive.

It is also urgent to investigate the influence of these determinants in different communities, in order to respond to the specificities, particularities, and potentialities of each community for an intervention adjusted to these realities. Here, health professionals with community intervention play a crucial role in empowering the individual to make conscious decisions about their habits, which generates autonomy for the continuous improvement of their health [12].

\section{HL: Context}

The World Health Organization [10], and some authors [13-15], present HL in different domains in the health context, focusing on access to HC, disease prevention (DP), and health promotion (HP). In turn, healthrelated information can be processed at the levels of access, understanding, evaluation, and its use/application. 
Table 1. Matrix of the $12 \mathrm{HL}$ subdimensions used by Espanha et al. [5]

\begin{tabular}{lllll}
\hline HL & $\begin{array}{l}\text { Access information } \\
\text { relevant to health }\end{array}$ & $\begin{array}{l}\text { Understand information } \\
\text { relevant to health }\end{array}$ & $\begin{array}{l}\text { Evaluate information } \\
\text { relevant to health }\end{array}$ & $\begin{array}{l}\text { Use information relevant to } \\
\text { health }\end{array}$ \\
\hline HC & $\begin{array}{l}\text { Ability to access medical } \\
\text { or clinical information }\end{array}$ & $\begin{array}{l}\text { Ability to understand } \\
\text { medical information and } \\
\text { its meaning }\end{array}$ & $\begin{array}{l}\text { Ability to evaluate medical } \\
\text { information }\end{array}$ & $\begin{array}{l}\text { Ability to make informed } \\
\text { decisions in medical matters }\end{array}$ \\
\hline $\mathrm{DP}$ & $\begin{array}{l}\text { Ability to access } \\
\text { information about risk } \\
\text { factors }\end{array}$ & $\begin{array}{l}\text { Ability to understand } \\
\text { information about risk } \\
\text { factors and their meaning }\end{array}$ & $\begin{array}{l}\text { Ability to interpret } \\
\text { information about risk } \\
\text { factors }\end{array}$ & $\begin{array}{l}\text { Ability to judge the relevance } \\
\text { of risk factors }\end{array}$ \\
$\begin{array}{l}\text { Health } \\
\text { promotion }\end{array}$ & $\begin{array}{l}\text { Ability to update health } \\
\text { topics }\end{array}$ & $\begin{array}{l}\text { Ability to understand } \\
\text { information related to } \\
\text { health and its meaning }\end{array}$ & $\begin{array}{l}\text { Ability to interpret and } \\
\text { evaluate health-related } \\
\text { information }\end{array}$ & $\begin{array}{l}\text { Ability to form mirrored } \\
\text { information }\end{array}$ \\
\hline
\end{tabular}

The present study followed these conceptual assumptions.

At the intersection of the different domains and levels of information processing, we utilized a matrix with a total of 12 subdimensions for HL [16] (Table 1). Each domain comprises a number of questions that are converted into an index, with a standardized scale ranging from 0 to 50 (minimum and maximum of $\mathrm{HL}$ ), using the following formula: index $=($ mean -1$) \times(50 / 3)$, where "index" represents the calculated specific index, "mean" is the average of all the items marked by each individual in the different questions, " 1 " is the average minimum possible value, " 3 " is the average range, and " 50 " is chosen from the new metric [15].

After the analysis of the indexes, HL was categorized, according to the points obtained, into four levels: inadequate $(0-25)$, problematic (26-33), sufficient (34-42), and excellent (43-50) [10,13-15]. After this categorization, the inadequate and problematic levels were grouped into a single level, designated limited [15].

Fawcett et al. [17] identified some determinants of HL, namely education, personal skills, early child development, aging, living and working conditions, gender, culture, and language. In an Australian study, it was concluded that $59 \%$ of the population aged between 15 and 74 years has a level of HL that does not allow them to respond to the demands of their daily lives [16], with emphasis on elderly people of non-English origin (within an English-speaking society) and people with low literacy as groups of greater vulnerability.

In the study by Pedro et al. [6] on the translation and validation of the European Health Literacy Survey (HLS$\mathrm{EU})$ for the Portuguese population, a sample of 1,004 individuals was taken at national level, including individu- als with limited HL. The subgroups with lower HL levels were: the elderly, the less educated, the unemployed, and the retired, all of which are considered vulnerable groups. The recognition of these groups is of enormous importance for health professionals, since knowing the HL level of subjects will enable them to adapt any and all interventions so that they are positioned and involved in the whole process.

\section{Objectives}

The present study was developed in the parish of Alto Minho and had the following objectives: (1) to assess the level of HL in this community, and (2) relate the HL level to sociodemographic variables (sex, age group, education, and employment situation).

\section{Methods}

This is a quantitative, observational, and cross-sectional study. The population selected for this study was 3,927 inhabitants in total, including 1,874 males and 2,053 females, representing a gender distribution that is identical to the Portuguese population [18]. Accordingly, respecting a fair population distribution, the sample was randomly probabilistically stratified by age and sex, through the sample size calculator da Raosoft ${ }^{\circledR}$, with a maximum sampling error of 5\%, obtaining a total sample of 351 individuals (161 males and 190 females), aged 15 years or older. Individuals with sensorycognitive and mental deficits that precluded communication were excluded. Interview by questionnaire was the methodology used to collect data via a random itinerary in the choice of street, building, and building floor, providing a random selection of addresses [5].

\section{Measure}

The data collection instrument selected was the adapted version of the HLS-EU for the Portuguese population, of the National School of Public Health at the New University of Lisbon [5]. This questionnaire consists of 5 modules that evaluate: information and 
Table 2. Sociodemographic characterization of the population sample $(n=351)$

\begin{tabular}{|c|c|c|c|c|}
\hline Variable & $n$ & $\%$ & Medium (SD) & Min./max. \\
\hline \multicolumn{5}{|l|}{ Sex } \\
\hline Male & 161 & 45.9 & & \\
\hline Female & 190 & 54.1 & & \\
\hline \multicolumn{5}{|l|}{ Age group } \\
\hline$\leq 64$ years & 276 & 78.6 & $44.94(19.048)$ & $15 / 88$ \\
\hline$\geq 65$ years & 75 & 21.4 & & \\
\hline \multicolumn{5}{|l|}{ Employment situation } \\
\hline Active & 214 & 61.0 & & \\
\hline Inactive & 137 & 39.0 & & \\
\hline \multicolumn{5}{|l|}{ Schooling } \\
\hline Without schooling, 1st and 2nd degree & 90 & 25.6 & & \\
\hline 3rd degree and high school & 170 & 48.4 & & \\
\hline Higher education & 91 & 25.9 & & \\
\hline
\end{tabular}

communication techniques and health, literacy, individual and family health perception, practices and attitudes in the field of HL, and sociodemographic characterization. Only two of these modules were used in the present study, namely module 5 (sociodemographic characterization) and module 1 , which has a Cronbach alpha of 0.96 on the 47 -issues scale (representing very good internal consistency, since it is higher than 0.920) [19] that assesses the complexity of the HL competencies of individuals, including users in need of $\mathrm{HC}$, individuals at risk who are involved in prevention services, and citizens seeking to promote their health. The formula (see above) is used both for the general index (covering the 47 questions) and for the different subindices: HC index (question 1-16), DP index (question 17-31), and HP index (question 32-47) [15].

After data collection, statistical analysis was performed using SPSS software version 24.0. The sociodemographic characterization of the sample was undertaken through descriptive statistics, using absolute numbers and relative frequencies, means, and standard deviation (SD). The $\chi^{2}$ test was used to evaluate the effect of sociodemographic variables on the different HL indexes, considering degrees of freedom and level of significance $(p=0.05)$.

Although we observed a significant effect of age group factors $\left(\chi^{2}=8.228 ; p=0.016\right)$ and schooling $\left(\chi^{2}=33.552 ; p \leq 0.001\right)$ in the dependent variable, it was not possible to confirm the logistic regression model. A larger sample and greater variability of the data would have allowed for more significant results.

\section{Results}

The surveyed population had a predominant female profile (54.1\%), aged between 15 and 88 years. The mean age $( \pm \mathrm{SD})$ was $44.94 \pm 19.048$ years and the majority (61\%) were professionally active (Table 2 ). Regarding HL, the internal consistency of the instrument in this sample assumed a behavior similar to that evidenced in the HL report in Portugal [12], with a Cronbach alpha of 0.97.
Table 3. HL levels of the community of Alto Minho within the different domains

\begin{tabular}{|c|c|c|c|c|c|c|}
\hline & \multicolumn{6}{|c|}{ Level of HL } \\
\hline & \multicolumn{2}{|c|}{ limited } & \multicolumn{2}{|c|}{ sufficient } & \multicolumn{2}{|c|}{ excellent } \\
\hline & $n$ & $\%$ & $n$ & $\%$ & $n$ & $\%$ \\
\hline General & 232 & 66.1 & 95 & 27.1 & 24 & 6.8 \\
\hline $\mathrm{HC}$ & 223 & 63.5 & 98 & 27.9 & 30 & 8.5 \\
\hline HP & 250 & 71.2 & 65 & 18.5 & 36 & 10.3 \\
\hline DP & 223 & 63.5 & 92 & 26.2 & 36 & 10.3 \\
\hline
\end{tabular}

The parish of Alto Minho has a limited level of HL (66.1\%), transverse to all subdimensions. In the HP subcategory, the proportion of individuals with limited HL was still higher (71.2\%) and only $6.8 \%$ of individuals presented excellent HL (Table 3 ).

In the critical analysis of the 47 questions, it could be verified that the task considered the easiest by most respondents was "call an ambulance in case of emergency," which represented $46.6 \%$ of answers.

In the access to HC field, more than $91 \%$ of respondents stated that "following instructions" (prescribed medication and medical or pharmaceutical indications) and the difficulty in evaluating "whether information on the disease in the media is reliable" (46.4\%) are easy tasks. In the DP domain, the task considered the easiest was "understand why you need to do routine medical exams" (96.8\%), and the most difficult was the "reliability assessment of information on health risks transmitted by the media of communication" (45.3\%). 
Table 4. HL levels according to the different sociodemographic variables

\begin{tabular}{|c|c|c|c|c|c|c|}
\hline \multirow[t]{2}{*}{ Variable } & \multicolumn{3}{|c|}{ HL level, \% } & \multirow[t]{2}{*}{$\chi^{2}$} & \multirow{2}{*}{$\begin{array}{l}\text { Degrees of } \\
\text { freedom }\end{array}$} & \multirow[t]{2}{*}{$p$} \\
\hline & limited & sufficient & excellent & & & \\
\hline \multicolumn{7}{|l|}{ Sex } \\
\hline Male & 67.1 & 25.5 & 7.5 & 0.490 & 2 & 0.783 \\
\hline Female & 65.3 & 28.4 & 6.3 & & & \\
\hline \multicolumn{7}{|l|}{ Age group } \\
\hline $15-24$ years & 64.3 & 28.9 & 6.8 & & & \\
\hline 25-64 years & 63.8 & 25.5 & 10.6 & & & \\
\hline$\geq 65$ years & 80.5 & 17.1 & 2.4 & 5.488 & 4 & 0.241 \\
\hline \multicolumn{7}{|l|}{ Employment situation } \\
\hline Active & 65.0 & 28.5 & 6.5 & 0.598 & 2 & 0.742 \\
\hline Inactive & 67.9 & 24.8 & 7.3 & & & \\
\hline \multicolumn{7}{|l|}{ Schooling } \\
\hline Without schooling, 1st and 2nd degree & 82.2 & 14.4 & 3.3 & 33.552 & 4 & 0.000 \\
\hline 3rd degree and high school & 68.8 & 27.1 & 4.1 & & & \\
\hline Higher education & 45.1 & 39.6 & 15.4 & & & \\
\hline
\end{tabular}

In HP, the easiest task was to "evaluate how housing conditions help you stay healthy" (88.7\%). "Know more about changes in policies that may affect your health" (13.2\%) was considered the most difficult in this area (and also in the overall index).

In relation to the sociodemographic variables with $\mathrm{HL}$, it was verified that there is no statistical evidence to support the existence of a significant relationship between HL and gender, as well as the situation with regard to employment (Table 4).

In this community, HL does not seem to be influenced by age. The only determinant that seems to influence HL is schooling $(p<0.01)$. However, there remains a significant percentage of individuals with limited HL (11.7\%; Table 4). We included the family income of the respondents as an indicator to determine whether or not it has a relationship with HL. However, a high percentage of respondents omitted this response and therefore it was not considered in the present analysis.

\section{Discussion}

A predominance of females is evident in national [6, $20,21]$ and international studies $[13,21,22]$. Therefore, the greater number of females can be justified in our study by the fact that in the municipality where the study was conducted women represent more than $50 \%$ of the total population [23]. The age profile of this sample is compatible with international studies [11] and is in agreement with the $66 \%$ of the population of this county aged between 15 and 64 years [24].

More than $74 \%$ of the sample has a literacy higher than compulsory schooling, which is in line with the $30.4 \%$ of the county's population with secondary and higher education, although $10 \%$ are illiterate [23]. The limited level of HL (66.1\%) in this parish is consistent with the findings of national studies $[5,7,10,15,25,26]$, with Portugal being below the European average according to the HL report in Portugal [5].

In all domains, individuals assume easy and very easy activities that incorporate functional HL, not involving critical analysis and interpretation of activity, and reveal greater difficulty in activities that require this capability. These results, according to the HL [5] report, should be read with caution, since considering a difficult or very difficult activity may manifest problems of literacy or greater attention and awareness of a certain difficulty given its complexity. This limitation will require professionals to readapt the way they work to create equal opportunities regardless of the individual's HL level. If an individual has greater difficulty in analyzing and interpreting, it will be necessary to create simple strategies to transmit the information and to promote health.

The relationship between HL and employment still lacks research. The active population (employees and students), which interacts actively with systems, has higher HL levels than those who are not active (retired, unemployed, and domestic). These results are similar to those found in the HL report for Portugal [5]. 
This finding should be evaluated with special attention because inactive people are more likely to have comorbidities as they age. Thus, those who use the health system more often have a limited HL level, which may be a barrier to professional intervention $[27,28]$.

As far as gender is concerned, there is no agreement with the results obtained in several studies. Some Portuguese $[15,24,29]$ and European studies [22] show that sex does not influence HL. On the one hand, in the comparative study of HL in eight European countries [13], a higher HL was observed in female subjects. Similar data were found in an e-Literacy study in youths/adolescents carried out in the city of Leiria [30]. On the other hand, in a study by Serrão et al. [25] involving 433 elderly Portuguese, male participants had higher levels of HL when compared to females.

The difference between studies with young people and studies with the elderly highlights the evolution of society. Today, contrary to the situation a few decades ago, women have equal access to education, which may explain the inexistence of a relationship between the gender and HL in this community of Alto Minho.

Although in the present study there was no statistically significant relationship between HL and age, this has been demonstrated in several national $[5,15,29,30]$ and international studies [13, 22, 31]. In the HL report [5], it is highlighted that "in all domains there is a transversal relation between the increase of the age of the individuals and the increase of the limitations in the accomplishment of tasks related to the HL." However, we highlight the study by Marques [14], in which there is no relationship between HL and age. With increasing age a smaller percentage of individuals with sufficient and excellent HL can be observed. This is a relevant fact, since it is with the advancement of years that many chronic diseases arise and there is evidence that limited HL is associated with worse health outcomes and also an inadequate use of health services [11].

$\mathrm{HL}$ also seems to be influenced by education, with individuals with higher levels of schooling having the highest levels of HL; however, a significant percentage (11.7\%) of individuals with limited HL cannot be neglected. Although this finding has been corroborated by several authors $[5,13,29]$, there are also studies in which there is no relationship between these variables [5].

In a district where $10.7 \%$ of the population is illiterate, $75.6 \%$ have 9 th grade and $14.2 \%$ higher education (there has been a $98 \%$ increase in people with this school level in last decade) [23]. Thus, the greater weight of the population has a level of schooling to which a smaller percentage of limited HL should correspond.

\section{Conclusion}

With this work we intend to offer a small and innovative contribution in the understanding of what is understood and encompasses HL. Although they cannot be extrapolated to the general population, the results of this study allowed us to determine the HL level of this Alto Minho community, which is characterized as limited. Also, the fact that it is related to certain sociodemographic variables has shed light upon the HL of the people of this community and on the challenges of promoting it, which together can be proposed for the development of good practices, namely access to information and lifelong learning opportunities.

Faced with a community with limited HL, it is necessary to carry out new studies that analyze the existence of a relationship between socioeconomic variables and $\mathrm{HL}$ in different communities, with a view to the intervention of health teams in individual, social, and cultural contexts, in the direction of its promotion.

\section{Acknowledgments}

We would like to thank Cátia Barbosa, Celsa Ferros, and Susana Evangelista for their help in the design of and data collection for the present study, and the entire population of Alto Minho for their receptivity and collaboration.

\section{Statement of Ethics}

All ethical requirements were met for this study.

\section{Disclosure Statement}

The authors declare no conflicts of interest.

\section{References}

1 World Health Organization. 7th Global Conference on Health Promotion, Nairobi, 26-30 October 2009: promoting health and development: closing the implementation gap. Geneva: WHO, 2009.

2 Ministério da Saúde. Direção-Geral de Saúde: Plano Nacional de Saúde: revisão e extensão a 2020. Lisbon: Direção-Geral de Saúde; 2015.

3 Despacho 6429/2017. Diário da República. 2a Série. No. 142 (2017 Jul 25): 15406-15406. Determina o programa "Literacia em saúde e integração de cuidados". 
4 Ministério da Saúde. Serviço Nacional de Saúde: SNS + Proximidade - Integração de Cuidados e Literacia em Saúde. Lisbon: Serviços Partilhados do Ministério da Saúde; 2017.

5 Espanha R, Ávila P, Mendes RV. Literacia em Saúde em Portugal. Lisboa: Fundação Calouste Gulbenkian; 2016.

6 Pedro AR, Amaral O, Escoval A. Literacia em saúde, dos dados à acção: tradução, validação e aplicação do European Health Literacy Survey em Portugal. Rev Port Saude Publica. 2016;34(3):259-75.

7 Saboga-Nunes L, Sorensen K, Pelikan JM. Hermenêutica da literacia em saúde e sua avaliação em Portugal (HLS-EU-PT). Évora: Universidade de Évora; 2014.

8 World Health Organization. Health promotion glossary. Geneva: WHO; 1998.

9 Nutbeam D. Health literacy as a public health goal: a challenge for contemporary health education and communication strategies into the 21st century. Oxford: Oxford University Press; 2000.

10 World Health Organization. Health literacy: the solid facts. Copenhagen: WHO; 2013.

11 Eichler K, Wieser S, Brügger U. The costs of limited health literacy: a systematic review. Int J Public Health. 2009;54(5):313-24.

12 Loureiro I, Miranda N. Promover a saúde: dos fundamentos à ação. Coimbra: Edições Almedina; 2010.

13 Sørensen K, Pelikan JM, Röthlin F, Ganahl K, Slonska Z, Doyle G, et al.; HLS-EU Consortium. Health literacy in Europe: comparative results of the European health literacy survey (HLS-EU). Eur J Public Health. 2015 Dec; 25(6):1053-8.
14 Marques JPD: Literacia em saúde: avaliação através do European Health Literacy Survey em português num serviço de internamento hospitalar [dissertation]. Lisbon: Instituto Universitário de Lisboa; 2015.

15 Gonçalves AM: Literacia em saúde e utilização dos serviços de saúde [dissertation]. Porto: Instituto Politécnico do Porto, Associação de Politécnicos do Norte; 2015.

16 Sørensen K, Van den Broucke S, Fullam J, Doyle G, Pelikan J, Slonska Z, et al.; (HLS-EU) Consortium Health Literacy Project European. Health literacy and public health: a systematic review and integration of definitions and models. BMC Public Health. 2012 Jan; 12(1):80.

17 Fawcett SB, Abeykoon P, Arora M, Munodawafa D. Constructing an action agenda for community empowerment at the 7th Global Conference on Health Promotion in Nairobi. Nairobi: Global Health Promotion; 2010.

18 Instituto Nacional de Estatística [Internet]. INE, 2011 [cited 2017 March 24]. Available from: http://www.ine.pt.

19 Pestana MH, Gageiro JN. Análise de dados para as ciências sociais: a complementaridade do SPSS. 6th ed. Lisboa: Edições Sílabo; 2014.

20 Amorim JC. Literacia e autocontrolo da dtipo 2 no Hospital de Santa Luzia [dissertation]. Viana do Castelo: Escola Superior de Saúde, Instituto Politécnico de Viana do Castelo; 2015.

21 Berkman ND, Sheridan SL, Donahue KE, Halpern DJ, Crotty K. Low health literacy and health outcomes: an updated systematic review. Ann Intern Med. 2011 Jul;155(2):97107.

22 Kondilis BK, Magoulas C, Ionnidis E, Agrafiotis D. The European Health Literacy Survey: Greece. Athens: Executive Agency for Health and Consumers; 2012.
23 Silva AM, Rosas M. Diagnóstico social de Viana do Castelo 2013: Relatório final. Viana do Castelo: Conselho Local de Ação Social; 2013.

24 Luís LFS: Literacia em saúde e alimentação saudável: os novos produtos e a escolha dos alimentos [thesis]. Lisbon, Escola Nacional de Saúde Pública, Universidade Nova de Lisboa; 2010.

25 Serrão C, Veiga S, Vieira I. Literacia em saúde: resultados obtidos a partir de uma amostra de pessoas idosas portuguesas. Rev Port Enferm Saude Mental. 2015;2:33-8.

26 Fernandes P. Literacia em saúde: contribuição para o estudo de adaptação e validação do NVS-Newest Vital Sign. Lisboa: Instituto Universitário de Ciências Psicológicas, Sociais e da Vida; 2012.

27 World Health Organization. Innovative care for chronic conditions: meeting report. Geneva: WHO; 2001.

28 Santos O. O papel da literacia em saúde: capacitando a pessoa com excesso de peso para o controlo e redução da carga ponderal. Endocrinol Diabetes Obes. 2010;4:127-34.

29 Cruz DM: Literacia em ehealth dos Portugueses: estudo exploratório [dissertation]. Covilhã: Faculdade de Ciências Sociais e Humanas, Universidade da Beira Interior; 2013.

30 Tomás CC: Literacia em saúde na adolescência [thesis]. Porto: Instituto de Ciências Biomédicas Abel Salazar, Universidade do Porto; 2014.

31 Toçi E, Burazeri G, Sørensen K, Kamberi H, Brand $\mathrm{H}$. Concurrent validation of two key health literacy instruments in a South Eastern European population. Eur J Public Health. 2015 Jun;25(3):482-6. 